\title{
Topography-modified refraction: adjustment of treated cylinder amount and axis to the topography versus standard clinical refraction in myopic topography-guided LASIK
}

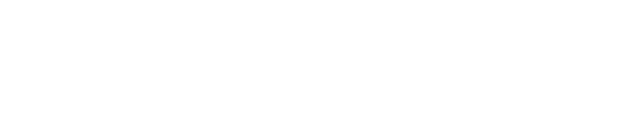

\author{
Noel Alpins ${ }^{1,2}$ \\ 'NewVision Clinics, Melbourne, \\ VIC, Australia; ${ }^{2}$ Department \\ Ophthalmology, Melbourne University, \\ Melbourne, VIC, Australia
}

\section{Dear editor}

It is encouraging to see the results in the article by Kanellopoulos "Topography-modified refraction (TMR): adjustment of treated cylinder amount and axis to the topography versus standard clinical refraction in myopic topography-guided LASIK", ${ }^{1}$ where the combination of refractive and corneal data in the treatment parameters provide better outcomes than treatment by optimal subjective refraction.

What is disappointing in the paper by Kanellopoulos is the omission in the reference list of the source references that first introduced and subsequently described treatment of patients with combined topography and refraction parameters. ${ }^{2-4}$ The omission of these references whether unintentional or deliberate has left Dr Kanellopoulos to make the false claim that his technique is "novel".

As Dupps described in his editorial in JCRS in Sep $2008^{5}$ the omission of source references "can distort the field by remapping key contributions inaccurately". Using my own work as an example, which is reinforced by Dr Kanellopoulos' erroneous claim of novelty, "this challenging issue can be addressed through errata and correspondence" as we are here, "but once in the literature such errors are prone to propagation". ${ }^{5}$

I ask Dr Kanellopoulos to update his reference list and modify his claims. The readers need to be informed of the origins of the method he used.

\section{Disclosure}

Dr Alpins has a financial interest in the ASSORT Surgical Management Systems used in the surgical planning and analysis of astigmatism.

\section{References}

1. Kanellopoulos AJ. Topography-modified refraction (TMR): adjustment of treated cylinder amount and axis to the topography versus standard clinical refraction in myopic topography-guided LASIK. Clin Ophthalmol. 2016;10:2213-2221.

2. Alpins NA. New method of targeting vectors to treat astigmatism. J Cataract Refract Surg. 1997;23: $65-75$.

3. Alpins NA, Stamatelatos G. Customized photoastigmatic refractive keratectomy using combined topographic and refractive data for myopia and astigmatism in eyes with forme fruste and mild keratoconus. $J$ Cataract Refract Surg. 2007;33:591-602.
NewVision Clinics 7 Chesterville Road,

Cheltenham, VIC 3192, Australia

Email alpins@newvisionclinics.com.au 
4. Alpins NA, Stamatelatos G. Clinical Outcomes for laser in situ keratomileusis using combined topography and refractive wavefront treatments for myopic astigmatism. J Cataract Refract Surg. 2008;34: $1250-1259$
5. Dupps WJ. Impact of citation practices: beyond journal impact factors. J Cataract Refract Surg. 2008;34:1419-1421.

Dove Medical Press encourages responsible, free and frank academic debate. The content of the Clinical Ophthalmology 'letters to the editor' section does not necessarily represent the views of Dove Medical Press, its officers, agents, employees, related entities or the Clinical Ophthalmology editors. While all reasonable steps have been taken to confirm the content of each letter, Dove Medical Press accepts no liability in respect of the content of any letter, nor is it responsible for the content and accuracy of any letter to the editor.

Clinical Ophthalmology

\section{Publish your work in this journal}

Clinical Ophthalmology is an international, peer-reviewed journal covering all subspecialties within ophthalmology. Key topics include: Optometry; Visual science; Pharmacology and drug therapy in eye diseases; Basic Sciences; Primary and Secondary eye care; Patient Safety and Quality of Care Improvements. This journal is indexed on
Dovepress

PubMed Central and CAS, and is the official journal of The Society of Clinical Ophthalmology (SCO). The manuscript management system is completely online and includes a very quick and fair peer-review system, which is all easy to use. Visit http://www.dovepress.com/ testimonials.php to read real quotes from published authors. 